\title{
Theory of unpleasant symptoms: support for the management of symptoms in children and adolescents with cancer
}

\author{
Teoria dos sintomas desagradáveis: subsídios para o manejo \\ de sintomas em crianças e adolescentes oncológicos \\ Teoría de los síntomas desagradables: subvenciones para \\ manejar síntomas en niños y adolescentes con cáncer
}

\author{
Luís Carlos Lopes-Júnior ${ }^{\mathrm{a}}$ \\ Emiliana de Omena Bomfim ${ }^{b}$ \\ Lucila Castanheira Nascimentoc \\ Gabriela Pereira-da-Silva ${ }^{c}$ \\ Regina Aparecida Garcia de Limac
}

D0l: $\quad$ http://dx.doi.org/10.1590/19831447.2015.03.51465

\footnotetext{
a Universidade de São Paulo (USP). Escola de Enfermagem de Ribeirão Preto (EERP/USP). Programa de Pós-Graduação Enfermagem em Saúde Pública. Ribeirão Preto, São Paulo, Brasil.

${ }^{b}$ Universidade de São Paulo (USP). Escola de Enfermagem de Ribeirão Preto (EERP/USP). Ribeirão Preto São Paulo, Brasil.

' Universidade de São Paulo (USP). Escola de Enfermagem de Ribeirão Preto (EERP/USP). Departamento de Enfermagem Materno-Infantil e Saúde Pública. Ribeirão Preto, São Paulo, Brasil.
}

\begin{abstract}
Objective: To present an overview of the clusters of neuropsychological symptoms in children and adolescents with cancer from the perspective of the Theory of Unpleasant Symptoms.

Methods: A theoretical and reflective study based on international literature and the critical analysis of the authors.

Results: In scientific literature, there is scarcity of international studies and an absence of studies in Brazil regarding the neuropsychological symptom clusters in children and adolescents with cancer. The theory of unpleasant symptoms is consistent because it emphasizes the complexity and interaction of the symptoms, the interrelationship between symptoms, the factors that influence symptoms, and the results and consequences of symptoms, thus supporting the planning of nursing interventions in paediatric oncology.

Conclusion: It is essential to update knowledge on this subject and discuss the theories that support research and the clinical practice of symptom management in order to better qualify nursing care.
\end{abstract}

Keywords: Concurrent symptoms. Neoplasms. Child. Adolescent. Oncology nursing.

\section{RESUMO}

Objetivo: Apresentar o panorama atual dos clusters de sintomas neuropsicológicos em crianças e adolescentes com câncer, na perspectiva da Teoria de Médio Alcance de Sintomas Desagradáveis.

Métodos: Estudo teórico-reflexivo baseado na literatura internacional e na análise crítica dos autores.

Resultados: A literatura científica apresenta resultados escassos internacionalmente e ausentes no Brasil, no que diz respeito aos clusters de sintomas neuropsicológicos em crianças e adolescentes com câncer. Esta é uma teoria consistente porque enfatiza a complexidade e a interação dos sintomas, as inter-relações entre os mesmos, os fatores que os influenciam e os resultados e consequências destes, corroborando o planejamento de intervenções de enfermagem em oncologia pediátrica.

Conclusão: Atualizar o conhecimento desse tema, bem como discutir as teorias que dão suporte à pesquisa e à prática clínica no manejo de sintomas, é parte fundamental para qualificar o cuidado de enfermagem.

Palavras-chave: Sintomas concomitantes. Neoplasias. Criança. Adolescente. Enfermagem oncológica.

\section{RESUMEN}

Objetivo: Presentar el panorama actual de grupos de síntomas neuropsicológicos en niños y adolescentes con cáncer, en perspectiva de Teoría de Síntomas Desagradables.

Métodos: Estudio teórico y reflexivo basado en la literatura internacional y el análisis crítico de los autores.

Resultados: La literatura científica presenta internacionalmente escasos resultados y que faltan en Brasil con respecto a los grupos de síntomas neuropsicológicos en niños y adolescentes con cáncer. Esta es una teoría consistente, ya que hace hincapié en complejidad e interacción de los síntomas, las interrelaciones entre ellos, los factores que influyen y los resultados y las consecuencias de éstos, el apoyo a la planificación de las intervenciones de enfermería en oncología pediátrica.

Conclusión: Actualizar el conocimiento sobre este tema, así como para discutir las teorías que apoyan la investigación y la práctica clínica en el manejo de los síntomas es fundamental para calificar el cuidado de enfermería.

Palabras clave: Síntomas concomitantes. Neoplasias. Niño. Adolescente. Enfermería oncológica. 


\section{DINTRODUCTION}

Children's cancer represents 1\% to 3\% of all malignant tumours in most populations ${ }^{(1)}$. In Brazil, from 2014 to 2015, the estimated average number of new cases of tumours among children aged 0 to 19 is 11.840 , and tumours are the leading cause of death by disease among children under 19 in all Brazilian regions ${ }^{(2)}$.

Although the cure and survival rates have improved significantly in recent decades, the long-term debilitating and intensive treatment leads to physical and behavioural symptoms that change the lives of these patients and their families ${ }^{(3)}$. Children and adolescents with cancer experience a variety of symptoms that sometimes occur simultaneously ${ }^{(4)}$. These symptoms are associated with a worse prognosis, including low survival rate, reduced treatment adherence and a diminished quality of life ${ }^{(4)}$. The importance of evaluating and intervening with the symptoms, both in terms of patient survival and of ensuring a better quality of life during and after treatment, is well established and is currently part of the pillars of research in clinical oncology and a priority in research in oncology nursing ${ }^{(5)}$.

Some of these symptoms can last for up to 10 years after the treatment and cure, and can influence experiences that can range from the patients' relationship with their bodies, their families, society and their social roles, to understanding their identity, values, and self-confidence ${ }^{(3)}$.

Nurses should acknowledge and be aware of the suffering of the children and adolescents with cancer who experience one or all of the symptoms of the various clusters. To manage the symptoms effectively, nursing interventions should include the evaluation of the symptoms individually and as whole in order to understand their interactive nature. The middle-range theory of unpleasant symptoms proposes that common factors can influence the experience of different symptoms, and therefore similar interventions can be effective in relieving one or more symptoms ${ }^{(6)}$. Whereas nursing theories standardize and systematize the approach to a given aspect, in a model capable of providing practical guidance in order to serve a clinical purpose, these theories provide a substantial theoretical basis that can help to describe, explore and predict phenomena of interest ${ }^{(7)}$.

A broader understanding of neuropsychological symptom clusters related to children's cancer in light of this theory might provide a basis for future care interventions for these patients. Consequently, the aim of this theoretical-reflexive paper is to present an overview of the clusters of neuropsychological symptoms in children and adolescents with cancer from the perspective of the middle-range theory of unpleasant symptoms.

\section{CANCER SYMPTOM CLUSTERS - FROM SICKNESS BEHAVIOUR TO NEUROPSYCHOLOGICAL SYMPTOM CLUSTERS}

Recently, researches involving symptom clusters have been proposed by nurses, specifically regarding studies that address the relationship between the occurrence of symptoms and their underlying dimensions ${ }^{(8)}$. The term cluster is defined as a group of symptoms that are related to each other and that can be predictable ${ }^{(9)}$. The current challenge for the exploration of symptom clusters is to clearly demonstrate the significance of a cluster in terms of interaction levels, patterns of association and synergy.

A neuropsychological symptom cluster was first observed when laboratory animals were inducted with infectious agents and injected with proinflammatory cytokines. This infectious and inflammatory condition resulted in a phenomenon called sickness behaviour ${ }^{(10)}$. Sickness behaviour refers to a grouping of physiological responses (fever, pain, increased activity of the hypothalamic-pituitary-adrenal axis and the autonomic nervous system) and behavioural responses (changes in sleep pattern, loss of interest in daily activities, dysphagia, decreased social interaction and sexual interest) that was originally discovered during experiments on murines ${ }^{(11)}$. Similarly, in humans, fatigue, pain, insomnia, depression and cognitive disorders were observed in patients with cancer that showed high levels of proinflammatory cytokine expression ${ }^{(12)}$.

The detection of sickness behaviour and neuropsychological symptoms suggests the communication between the immune system and the central nervous system, which orchestrates a set of responses that can trigger behavioural and physiological changes in humans and animals ${ }^{(10)}$. Therefore, the concept of sickness behaviour enables the appearance of a concept that is applied to human health; the neuropsychological symptom cluster. This is defined as a set of emotional and/or behavioural symptoms that can be related to a psychological and/or neurological dysfunction that tends to occur in cancer patients ${ }^{(11)}$.

Similarities between the symptoms of sickness behaviour and the neuropsychological symptom cluster in cancer patients supports the hypothesis that proinflammatory cytokines may be related to possible biological mechanisms and to the etiology of this symptom cluster ${ }^{(10)}$. The release of pro-and anti-inflammatory cytokines, such as IL-1 $\beta, I L-6, I L-8, I L-10, I L-12 p 70$, TNF-a and interferons may be related to the installation of a neuropsychological symptom condition, including depressed mood, fatigue, cognitive disturbance, anorexia, sleep disorders and increased sensi- 
tivity to pain. Scientific evidence suggests a consistency in the hypothesis that changes in cytokines and other neuroimmunological processes can be critical to the production of symptoms and, potentially, to the treatment and prevention of symptoms ${ }^{(8)}$.

A study based on a mixed linear model showed that adolescents who were experiencing higher levels of fatigue and suffered from more sleep disorders also presented more depressive symptoms and behavioural alterations ${ }^{(11)}$. The symptoms of several clusters can also be grouped together and create a synergistic effect or a predecessor effect. This means that a single symptom can exist within a cluster. This symptom is called a predictor because it is associated with the likelihood of a cluster symptom ${ }^{(13)}$. When this predictor symptom is identified, it is called a sentinel symptom ${ }^{(14)}$.

An understanding of the experiences of children and adolescents with several neuropsychological symptom clusters can provide a scientific basis for new nursing interventions, mainly in relation to managing concomitant symptoms and enabling the identification of signs and symptoms that will help predict other relevant clusters.

\section{The middle-range theory of unpleasant symptoms}

The theory of unpleasant symptoms (TUS) is a middle-range theory that was created and introduced in 1995 by research nurses who were engaged in clinical practice ${ }^{(6)}$. This theory has three main components: the symptoms the individual is experiencing, the factors that influence or affect symptoms and that give rise to the nature of the symptoms, and the consequences of this experience. Each symptom is considered a multidimensional experience that can be measured separately or together with other symptoms. Although symptoms differ from each other, they share some dimensions, such as intensity, time, degree of perceived suffering and quality. In this theory, three factors influence such dimensions: 1) physiological factors; 2) psychological factors; and 3) situational factors, which cause individuals to experience the same symptoms in different ways ${ }^{(4,6)}$.

TUS encourages nurses to seek new clusters of symptoms and propose non-pharmacological interventions for the management of these symptoms ${ }^{(6)}$. Unpleasant symptoms, their interaction, synergy and complexity are experienced daily by patients who receive care. To identify potential factors of influence, this theory provides a framework that helps to determine the extent of the overlap between the symptoms at a level of abstraction that is compatible with nursing diagnoses and interventions ${ }^{(15)}$.
The translation of nursing theories for their application in the professional care context is a current challenge for both research nurses and practicing nurses. Middle and long range theories enable nurses to combine clinical practice and theory, and to study, explore, plan, or survey the science of nursing and its respective theories ${ }^{(15)}$. They also include and combine concepts related to the experience of physical and subjective symptoms so that they can be easily applied to practice in specific populations (children, adolescents, adults and the elderly) and in particular situations (treatable cancers and palliative care, for example). This range of concepts presented by the TUS favours the creation and implementation of new ideas that are translated into new practices and knowledge for the provision of better healthcare ${ }^{(15)}$.

\section{GINAL CONSIDERATIONS}

There is potential for the advancement of science in the field of neuropsychological symptom clusters, and their evaluation and interactions, in children and adolescents with cancer. Similarly, the evaluation of changes in the severity of these symptoms over time through the biological mechanisms involved in their genesis is a promising proposal. Although researchers are currently exploring the biological pathways of these symptoms in adults with cancer, among children and adolescents with cancer these efforts are still in the early stages.

In addition to understanding the experiences of symptoms in children with cancer, the need to link the clinical practice of nursing to an understanding of the biological mechanism of symptoms reported by cancer patients is even more critical, especially regarding the occurrence, interaction and synergy of these symptoms.

Until more definitive studies of symptom clusters are carried out, nurses should pay extra attention to patient reports and should be qualified to monitor, identify and record the occurrence of multiple symptoms in order to create more personalized care plans.

TUS is a powerful tool that can be used to understand neuropsychological symptoms in children and adolescents with cancer, and it provides a useful and consistent theoretical framework for planning nursing interventions. This theory offers a wide range of uses because it emphasizes the complexity and interaction of symptoms, their correlations, the factors that influence symptoms, and the results and consequences of symptoms. The assumption that there is an interrelationship between the symptoms presented by the TUS is quite 
challenging. When symptoms are examined in their entirety and nursing interventions are created on the basis of the interactive nature of symptoms, these interventions becomes specific and personalized for each user, and therefore more effective.

\section{REFERENCES}

1. Siegel R, Ma J, Zou, Z, Jemal A. Cancer statistics, 2014. CA Cancer J Clin. 2014;64(1):9-29.

2. Instituto Nacional de Câncer (BR). Coordenação de Prevenção e Vigilância. Estimativa 2014: incidência de câncer no Brasil. Rio de Janeiro: INCA; 2014.

3. Melaragno R, Camargo B. Oncologia pediátrica: diagnóstico e tratamento. São Paulo: Atheneu; 2013.

4. Rodgers CC, Hooke MC, Hockenberry MJ. Symptom clusters in children. Curr Opin Support Palliat Care. 2013;7(1):67-72.

5. Barsevick AM, Irwin MR, Hinds P, Miller A, Berger A, Jacobsen P, et al. Recommendations for high-priority research on cancer-related fatigue in children and adults. J Natl Cancer Inst. 2013;105(19):1432-40.

6. Lenz ER, Pugh L. Theory of unpleasant symptoms. In: Smith M, Lierh P. Middle range theory for nursing. 2nd ed. New York; 2008. p. 159-83.
7. Im E0. Situation-specific theories from the middle-range transitions theory. Adv Nurs Sci. 2014;37(1):19-31.

8. Kim HJ, Barsevick AM, Fang CY, Miaskowski C. Common biological pathways underlying the psychoneurological symptom cluster in cancer patients. Cancer Nurs. 2012;35(6):e1-e20.

9. Dodd MJ, Miaskowski C, Lee KA. Occurrence of symptom clusters. J Natl Cancer Inst Monogr. 2004;(32):76-8.

10. Dantzer R, Kelley KW. Twenty years of research on cytokine-induced sickness behavior. Brain Behav Immun. 2007;21(2):153-60.

11. Hockenberry MJ, Hooke MC, McCarthy K, Gregurich MA. Sickness behavior clustering in children with cancer. J Pediatr Oncol Nurs. 2011;28(5):263-72.

12. Barsevick AM, Whitmer K, Nail L, BeckS, Dudley WM. Symptom cluster research: conceptual, design, measurement, and analysis issues. J Pain Symptom Manage. 2006; 31(1):85-95.

13. Berger AM, Yennu S, Million R. Update on interventions focused on symptom clusters: what has been tried and what have we learned? Curr Opin Support Palliat Care. 2013;7(1):60-6.

14. Aktas A. Cancer symptom clusters: current concepts and controversies. Curr Opin Support Palliat Care. 2013;7(1):38-44.

15. Espinoza Venegas M, Valenzuela Suazo S. Análisis de la teoría de los síntomas desagradables en el cuidado de la enfermería paliativa oncológica. Rev. Cubana Enfermer. 2011;27(2):141-50.

\section{Author's address:}

Luís Carlos Lopes-Júnior

Av. Bandeirantes, 3900, Campus Universitário

14040-902 Ribeirão Preto - SP

E-mail: luisgen@usp.br
Received: 10.11.2014

Approved: 03.07.2015 